\title{
Tadeusz Lewowicki, Barbara Grabowska, Urszula Klajmon-Lech, Aniela Różańska, Sfery życia duchowego dzieci i młodzieży - studium z pogranicza polsko-czeskiego. Tom 2. Religia i tolerancja religijna ${ }^{1}$
}

Czytając w tytule tomu "religia” i „tolerancja religijna”, można sądzić, że jest to praca z zakresu pedagogiki religii. Z kolei Tadeusz Lewowicki we „Wstępie” (2016b) zwraca uwagę, że pojęcie „życie duchowe”, które zawarte jest w tytule głównym, rzadko pojawia się w tytułach głównego nurtu pedagogicznego, jest ono przede wszystkim używane w pracach z zakresu pedagogiki chrześcijańskiej (Lewowicki, 2016b, s. 9). Tymczasem - jak pisze autor życie człowieka to życie m.in. aksjologiczne, poznawcze, afektywne czy życie religijne i każde z tych pojedynczych wymiarów decyduje o egzystencji człowieka (Lewowicki, 2016b, s. 10). Badanie stosunku, relacji czy postaw człowieka do rozmaitych kwestii życia religijnego pozwala rozpoznać stosunek, relacje czy też postawy człowieka także wobec Innego-Religijnie. Jednocześnie ów stosunek, relacje czy postawy do Człowieka Innego-Religijnie można traktować jako reprezentację stosunku, relacji czy postawy społeczności większościowej do społeczności mniejszościowej (Lewowicki, 2016b, s. 10). Zatem treści książki zdecydowanie wykraczają poza przywołane subdyscypliny naukowe i tym samym kwalifikują tom w obręb pedagogiki społecznej (a właściwie do pedagogiki wspólnoty) i pedagogiki międzykulturowej.

Podstawową zasadą książki Religia i tolerancja religijna jest postawiona przez Anielę Różańską teza o konieczności rozróżnienia tożsamości religijnej jako wartości samej w sobie od tożsamości religijnej jako wartości kulturowej. Pierwsza - jak przekonuje badaczka - to tożsamość relacyjna, która jest efektem osobistego doświadczenia człowieka; jest ona tym, co nabywa się i co wybiera się świadomie. Jest ona efektem religii, czyli inaczej relacji człowieka

1 Lewowicki, T., Grabowska, B., Klajmon-Lech, U. i Różańska, A. 2016. Sfery życia duchowego dzieci i młodzieży - studium z pogranicza polsko-czeskiego. T. 2. Religia i tolerancja religijna. Toruń: Wydawnictwo Adam Marszałek, ss. 164. 
i Boga. Druga - to także tożsamość relacyjna, ale jest ona odziedziczona po przodkach i ma charakter społeczno-kulturowy. Jest efektem kultury, czyli relacji człowieka i wspólnoty (Różańska, 2016b, s. 68). Rozróżnienie jest kluczowe, gdyż zwykle to, co określa się mianem religijności i postaw religijnych, jest zaledwie pokłosiem procesów kulturowych (takich jak socjalizacja czy wychowanie) w obrębie własnej wspólnoty. Świadomość tego faktu ma znaczenie pedagogiczne i edukacyjne, gdyż krytyczna refleksja może pomóc choćby w tym, by edukacyjnie rozmontować „źle pojęty patriotyzm”, który „rodzi strach, uprzedzenia, a nawet i wrogość” (Różańska, 2016b, s. 63). Zrozumienie różnic, czym w istocie jest religijność, a czym kulturowość człowieka i wspólnoty, jest jednym z filarów konstruowania społeczeństwa wielokulturowego, a także konstruowania tożsamości „otwartej na Innych religijnie, na ich odmienność kulturową i religijną" (Różańska, 2016b, s. 68).

Nim przejdę do dalszej dyskusji nad książką, powinnam zasygnalizować dwie kwestie metodologiczne, do których wprowadza Różańska (2016a). Po pierwsze, badania przedstawione w książce zostały przeprowadzone w latach 2014-2015; weszły one w skład badań panelowych i są odnoszone do wyników pozyskanych przez badaczy w roku 1998 i roku 2009. Celem było/ jest rozpoznanie stanu religijności i postaw religijnych młodzieży pogranicza polsko-czeskiego, obejmującego społeczno-kulturowy i historyczno-polityczny obszar Śląska Cieszyńskiego. Dzięki użytej metodzie badacze mogli rozpoznać kondycję społeczności polskiej po obu stronach Olzy, a także kondycję społeczności czeskiej (Różańska, 2016a, s. 16). Po drugie, interpretacja materiału empirycznego realizowana jest w obrębie teorii/filozofii religii jako relacji. Podstawowymi pojęciami są tu „spotkanie”, „dialog”, „współpraca”, "człowiek”, „kultura” i „tożsamość” (Różańska, 2016a, s. 12). Innymi słowy, religia i religijność to koncepty teoretyczne, które dotyczą wspólnoty, gdyż w swoisty dla siebie sposób ją organizują. Praktycznymi wymiarami wspólnoty są: człowiek, spotkanie, dialog, współpraca, kultura i tożsamość.

Zaproponowana przez autorów struktura książki koncentruje się wokół pojęć: „tolerancji religijnej” i „otwartości” (Grabowska, 2016), „tożsamości religijnej” i „otwartości - zamknięcia” (Różańska, 2016b) i „doświadczenia wspólnotowości” (Klajmon-Lech, 2016). Autorzy jednak napisali książkę, która otwarta jest na inne możliwości interpretacyjne i wręcz zachęca do dyskusji. Gdyby więc Religię i tolerancję... rozpoznać poprzez antropologiczne wątki, do czego zachęca rozdział pisany przez Różańską (2016b), to można mówić o dwóch wątkach interpretacyjnych: o antropologii pogranicza (rozumianego jako region zróżnicowany kulturowo, społecznie i religijnie) 
w rozdziale autorstwa Barbary Grabowskiej (2016) i o antropologii wspólnoty (rozumianej jako świadomość) - w części pisanej przez Urszulę Klajmon-Lech (2016).

Człowiek Różańskiej to człowiek uwikłany w relację z Bogiem i jednocześnie w relację ze wspólnotą. Proponowana przez badaczkę antropologia konstruowana jest poniekąd na dwóch imperatywach: jednym jest Bóg, drugim wspólnota. Wspólnota jest dla człowieka koniecznością, gdyż to w niej dzieją się relacje człowieka z człowiekiem, dla których wzorem jest relacja człowieka z Bogiem i Boga z człowiekiem. Tak ujęta dyskusja o człowieku jest gruntowana w symbolice tego, co otwarte i tego, co zamknięte, i równocześnie jest ona konstruowana w obszarze tego, co wspólnotowe. Autorka stopniowo przekonuje czytelnika do tezy, że człowiek potrzebuje Innego, aby móc poznać siebie (Różańska, 2016b, s. 66). Więcej, Różańska zdaje się przekonywać, że człowiek powinien, jeśli nie dla Innego, to dla siebie (jakby z „czystego egoizmu” - uwaga A.K.) dążyć do wspólnotowości, a w jej obrębie do relacji z Innym, gdyż tylko tak może człowiek tworzyć siebie. Odnieść można nawet wrażenie, że relacja z Bogiem może być pozbawiona sensu w sytuacji, w której człowiek pozbawiony zostanie wspólnoty, a więc wtedy, gdy zostanie zupełnie sam. Tylko z Bogiem i tylko ze wspólnotą człowiek może tworzyć/formować/konstruować siebie (Różańska, 2016b, s. 64-66, s. 68-69, 76 i nn.). Tylko w obrębie wspólnoty człowiek może uczyć się otwartości na różnice kulturowe. Wspólnota religijna jest szczególną egzemplifikacją życia wspólnotowego. Jak każda wspólnota może ona uczyć człowieka otwartości wobec innych wspólnot, ale może też uczyć zamknięcia. Ma to miejsce choćby wtedy, gdy wspólnota uzna siebie za "monopolistę" jedynie „prawdziwej prawy” o Bogu, świecie i ludziach (Różańska, 2016b, s. 78).

Młodzież wychowana w warunkach różnicy religijnej i wyznaniowej to jak pokazują badania Różańskiej - ludzie, którzy częściej zauważają pozytywne cechy tej różnicy, choć nadal mogą doświadczać wobec niej niepewności czy lęku. Takie emocje są jednak uznane za nietolerancyjne i wywołujące konflikty (Różańska, 2016b, s. 80-83). Postawy młodych ludzi wobec różnicy religijnej i wyznaniowej właściwie nie uległy zmianie od 1998 r., co uwidoczniło porównanie wyników badań z lat 2015 i 1998. Na tym tle interesująco przedstawia się nastawienie młodych wobec ekumenizmu. Młodzi ludzie mają kłopot w zdefiniowaniu tego zjawiska (Różańska, 2016b, s. 85), równocześnie są oni świadomi potrzeby współpracy między różnymi wyznaniami (Różańska, 2016b, s. 86), co jednak nie przekłada się na masową aktywność młodych w tym obszarze (Różańska, 2016b, s. 86). Być może - a do takiej 
tezy skłaniają interpretacje Badaczki (Różańska, 2016b, ss. 90-92) - jest to zaniedbały aspekt wychowania szkolnego, który można ująć jako jeden z zaniedbanych obszarów wychowania wielokulturowego i międzykulturowego.

Pogranicze jako miejsce zamieszkane przez człowieka jest interesującym przedmiotem badań, po który chętnie sięga się w naukach społecznych. Ze względu na zróżnicowanie kulturowe, religijne czy wyznaniowe pogranicze staje się polem eksploracji pedagogiki międzykulturowej, gdyż skłania m.in. do przemyśleń antropologiczno-pedagogicznych. Grabowska (2016) wskazuje tolerancję jako jedną z wielu możliwości egzystencji człowieka w regionie wewnętrznie zróżnicowanym. Autorka pisze, że jakkolwiek tolerancja dotyka bezpośrednio egzystencji człowieka, to z konieczności potrzebuje ona umocowania w systemie prawnym (Grabowska, 2016, ss. 22-23, s. 28). Jednocześnie to, czym jest tolerancja i jakie jej wymiary są realizowane na pograniczu, zależy od historii społecznej i politycznej danego regionu. Poznanie więc dziejów pogranicza pozwala zrozumieć specyfikę miejsca i jego (nie) wrażliwość na sprawy zróżnicowania kulturowego, społecznego i religijnego. Tolerancja jako postawa człowieka wobec innych wspólnot kulturowych i religijnych jest wypadkową dziejów społeczności pogranicza (Grabowska, 2016, s. 38 i nn.), historyczności własnej wspólnoty kulturowej czy religijnej (Grabowska, 2016, ss. 40-45), jakości życia społecznego państwa/ państw tworzących pogranicze (region) (Grabowska, 2016, s. 46), a także celowych procesów edukacyjnych podejmowanych w obrębie pogranicza (regionu) i państwa/państw (Grabowska, 2016, s. 47 i nn.).

Jednak to nie pogranicze-region jest najbliższe człowiekowi, lecz wspólnota - jak udowadnia Klajmon-Lech (2016) - ponieważ tylko za pośrednictwem wspólnoty człowiek może zobiektywizować się realnie i symbolicznie. Tego też dowodzi krytyczna dyskusja Różańskiej, której wybrane aspekty przedstawiłam wcześniej.

Konstruowana przez Klajmon-Lech antropologia bazuje na rozumieniu wspólnoty jako stanu ducha i umysłu; jako towarzyszące człowiekowi poczucie przynależności i wzajemności. Tylko bowiem w tak pojmowanej wspólnocie człowiek może realizować swą potrzebę intymności, a mogąc zaufać innym, może on realizować swą potrzebę autonomii (Klajmon-Lech, 2016, ss. 97-99). Wspólnota jest więc świadomością (ideologią?), która konstruuje świadomość człowieka i zwrotnie człowiek dzięki swej świadomości może angażować się w wytwarzanie, a także trwanie wspólnoty.

W przypadku wspólnot religijnych czy wyznaniowych faktem jest, że często konstruują się one na odmiennych zasadach, jak to ma miejsce w przypadku 
wspólnot katolickiej i ewangelickiej (Klajmon-Lech, 2016, ss. 99-101). Niemniej jednak Klajmon-Lech rozpoznaje wspólne im obszary psychologiczny, socjologiczny, pedagogiczny i edukacyjny. Psychologicznie idzie o przeżywanie siebie w jednostkowych doświadczeniach z Bogiem i z Innymi. Socjologicznie - chodzi o wspólne zainteresowania, podzielaną społecznie egzystencję i wspólny cel (Klajmon-Lech, 2016, s. 102 i nn.). Już z tych dwóch przesłanek wynika, że przeżycia religijne są zaledwie motywatorem, który składania człowieka do afiliacji i angażowania się we wspólnotę. Jeśli więc człowiek ma na uwadze dobro własne, to (egoistycznie - uwaga A.K.) powinien dbać o wspólnotę, jako że tylko tu może realizować swe potrzeby psychologiczne i społeczne (Klajmon-Lech, 2016, s. 104 i nn.). Edukacyjnie ważnym jest angażowanie się człowieka we wspólnotę (tu: w grupy religijne) nie tylko ze względu na rozwój i trwanie wspólnoty (Klajmon-Lech, 2016, s. 111), ale ze względu na wartości (Klajmon-Lech, 2016, s. 111), których nośnikiem jest wspólnota, dlatego że decydują one o kondycji człowieka. Wspólnota zapewnia dostęp do relacji osobowych (Klajmon-Lech, 2016, s. 112), w których człowiek może uczyć się swej autonomii (Klajmon-Lech, 2016, s. 114). Pedagogicznie i edukacyjnie niepokoić zatem powinno, że młodzi w deklaracjach (pozyskanych w latach 2014-2015) nie angażują się w działalność grup religijnych (tak katolickich, jak i ewangelickich). Stąd zapewne postulat badaczki, by pytać młodych o przyczynę tego stanu rzeczy (Klajmon-Lech, 2016, s. 123).

Tadeusz Lewowicki (2016a), dokonując podsumowania, zwraca uwagę na dwie sprawy. Pierwsza wiąże się z faktem, że religia i religijność są wykorzystywane jako elementy tożsamości narodowej. Ich wewnętrzna struktura znaczeniowa jest uwarunkowana dziejami społeczno-politycznymi, co przekłada się na to, że religia jest kultywowana w określony sposób na danym terytorium narodowym (Lewowicki, 2016a, s. 127). Duchowość może być więc - jak pisze autor - formą „sprzeciwu wobec warunków społeczno-politycznych" i elementem podtrzymującym „tożsamość religijną i narodową" (Lewowicki, 2016a, s. 127). Toteż zmiana warunków życia publicznego pociąga za sobą zmianę instytucjonalnych i publicznych form życia religijnego (Lewowicki, 2016a, s. 129).

Druga ważna kwestia wiąże się z postrzeganym przez człowieka znaczeniem wspólnoty dla jego życia. Autorzy książki wyraźnie dostrzegają kryzys wspólnotowości jako doświadczenia biograficznego i edukacyjnego. Sprawa wydaje się poważna, gdyż wspólnota stanowi przestrzeń konstruowania postaw społecznych. I stąd obserwowane przemiany w obrębie życia wspólnotowego powinny skłaniać do krytycznej refleksji i być motywatorem do 
zmian w obrębie edukacji, w tym edukacji międzykulturowej (Lewowicki, 2016a, s. 137).

Jeśli bowiem traktować wspólnotę jako środowisko wychowujące, to z konieczności mierzyć się ono powinno także z różnicą kulturową, religijną i wyznaniową (Lewowicki, 2016a, s. 137). Kształtowanie postaw otwartości i tolerancji nie dzieje się - jak zdają się przekonywać Tadeusz Lewowicki i inni autorzy tej książki - w społeczeństwie, lecz we wspólnotach, których formuła konstruowana jest na osobistym i emocjonalnym zaangażowaniu człowieka. A najbliższymi człowiekowi wspólnotami są wspólnoty parafialne i kościelne. Stąd być może obserwowany ruch społeczny, na mocy którego obok religijnych form instytucjonalnych (formalnych) powstają formy wspólnotowe (Klajmon-Lech, 2016, ss. 99-101), które pozwalają człowiekowi realizować to, co w ramach filozofii personalistycznej nazwać trzeba osobowym byciem człowieka. Obserwowany kryzys wspólnoty zdaje się dotykać nie tyle odczuwanych przez człowieka potrzeb życia wspólnotowego, ile pewnego wyczerpania się instytucjonalnej formuły wspólnoty. I nie idzie o to, że minęła moda na życie wspólnotowe, ale zinstytucjonalizowana forma wspólnoty przestała troszczyć się o duchowy wymiar człowieczej egzystencji (Klajmon-Lech, 2016, ss. 113-124).

Zatem $\mathrm{z}$ tej perspektyw niedostrzegana jest owa różnica w zakresach semantycznych tożsamości religijnej. Ta - we właściwym tego słowa znaczeniu - ma być wynikiem osobistego doświadczenia człowieka, nabywanego w obszarze relacji z Bogiem (Różańska, 2016b, s. 68). Z perspektywy wspólnotowej rozpoznawalny jest prawie wyłącznie kulturowy wymiar tożsamości religijnej, w taki sposób, że staje się ona składową identyfikacji społecznej, konstruując tym samym wspólnotowe wyobrażenie identyfikacyjne. To wtórnie może decydować o stosunku do Innych i Obcych. Książka wyraźnie wskazuje, że łatwiej o otwartość i tolerancję wtedy, gdy różnica religijna i wyznaniowa stanowi immanentną cechę codzienności człowieka. Taka sytuacja sprzyja wyłączaniu identyfikacji religijnej ze sfery konstruującej tożsamość narodową. Innymi słowy, zróżnicowanie religijne i wyznaniowe powoduje, że narodowość nie jest w prosty sposób potwierdzana identyfikacją religijną bądź wyznaniową (Lewowicki, 2016a, ss. 130-131 i nn.).

Domykając wątek, powinnam podkreślić, że książka Religia i tolerancja religijna jest pedagogicznie ważnym przyczynkiem do dyskusji nad kondycją wspólnotowego życia człowieka. Przekornie jednak napiszę, że być może rezygnacja ze wspólnoty i wspólnotowości to przejaw człowieczego oporu, wobec - być może subiektywnie odczuwanej i/lub być może obiektywnie doświadczanej - opresyjności niektórych wspólnot. 


\section{Bibliografia}

Grabowska, B. 2016. Tolerancja religijna młodzieży żyjącej na Pograniczu. W:

Lewowicki, T., Grabowska, B., Klajmon-Lech, U. i Różańska, A. Sfery życia duchowego dzieci i młodzieży-studium z pogranicza polsko-czeskiego. T. 2. Religia i tolerancja religijna. Toruń: Wydawnictwo Adam Marszałek, ss. 21-61.

Klajmon-Lech, U. 2016. Doświadczenie wspólnoty wśród młodzieży Śląska Cieszyńskiego. W: Lewowicki, T., Grabowska, B., Klajmon-Lech, U. i Różańska, A. Sfery życia duchowego dzieci i młodzieży - studium z pogranicza polsko-czeskiego. T. 2. Religia i tolerancja religijna. Toruń: Wydawnictwo Adam Marszałek, ss. 96-126.

Lewowicki, T. 2016a. Stałość i zmienność stosunku do kwestii związanych z religią i do Innych religijnie/wyznaniowo - próba porównania. W: Lewowicki, T., Grabowska, B. ,Klajmon-Lech, U. i Różańska, A. Sfery życia duchowego dzieci i młodzieży - studium z pogranicza polsko-czeskiego. T. 2. Religia i tolerancja religijna. Toruń: Wydawnictwo Adam Marszałek, ss. 127-137.

Lewowicki, T. 2016b. Wstęp. W: Lewowicki, T., Grabowska, B., Klajmon -Lech, U. i Różańska, A. Sfery życia duchowego dzieci i młodzieży - studium z pogranicza polsko-czeskiego. T. 2. Religia i tolerancja religijna. Toruń: Wydawnictwo Adam Marszałek, ss. 9-11.

Różańska, A. 2016a. Młodzież z Pogranicza - uczniowie ze szkół ponadgimnazjalnych w roku 2015 - charakterystyka środowiska i badanych grup. W: Lewowicki, T., Grabowska, B., Klajmon-Lech, U. i Różańska, A. Sfery $\dot{z}$ ycia duchowego dzieci i młodzieży - studium z pogranicza polsko-czeskiego. T. 2. Religia i tolerancja religijna. Toruń: Wydawnictwo Adam Marszałek, ss. 12-20.

Różańska, A. 2016b. Postrzeganie Inności religijnej jako element tożsamości religijnej młodzieży Śląska Cieszyńskiego - między zamknięciem a otwartością. W: Lewowicki, T., Grabowska, B., Klajmon-Lech, U. i Różańska, A. Sfery życia duchowego dzieci i młodzieży - studium z pogranicza polsko -czeskiego. T. 2. Religia i tolerancja religijna. Toruń: Wydawnictwo Adam Marszałek, ss. 62-95. 